\section{"Kuinka tukea aikuisia kestävän tulevaisuuden rakentajina?"}

Joensuulaista tukijaa Toni Kososta, 37, kiinnostavat erityisesti aikuisten ohjauksen kysymykset.

MINUSTA TULI TUTKIJA, koska päädyin mukaan kiinnostaviin tutkimusprojekteihin. Aloitin sosiologian opinnot vuonna 2001 Joensuun yliopistossa. Laitoksella on pitkät tutkimusperinteet kasvatus- ja koulutussosiologian sekä erityisesti aikuiskoulutuksen aloilta. Kun vuonna 2005 tein opintoihin kuuluvaa harjoittelua, pääsin tutkimusavustajaksi ja sittemmin tutkijaksi kasvatussosiologian professori Ari Antikaisen tutkimushankkeisiin.

Vuosina 2007-2011 työskentelin valtakunnallisen Noste-aikuiskoulutusohjelman seurantatutkimushankkeissa. Noste oli hieno näköalapaikka aikuiskoulutuksen kentälle, koska siihen sisältyi tiivistä yhteistyötä paikallisten Noste-hankkeiden kanssa ja työseminaarikiertue aikuisoppilaitoksissa ympäri maata.

Hanketyö antoi pohjan tutkijan työhön kasvamiselle. Nosteessa kiinnostuin miehistä aikuiskoulutuksen syrjään jävänä," ongelmallisena" ryhmänä: he olivat selvästi aliedustettuja tutkimusaineistoissamme.

Sosiologian alan väitöstutkimuksessani haastattelin 32 ammatilliseen aikuiskoulutukseen osallistunutta miestä. Selvitin, miten miehet rakentavat suhdettaan aikuiskoulutukseen ja -opiskeluun ja miten he vastaavat normatiivisiin yhteiskunnallisiin odotuksiin elinikäisestä oppimisesta. Samalla miehet pioita monimuotoisemmaksi.

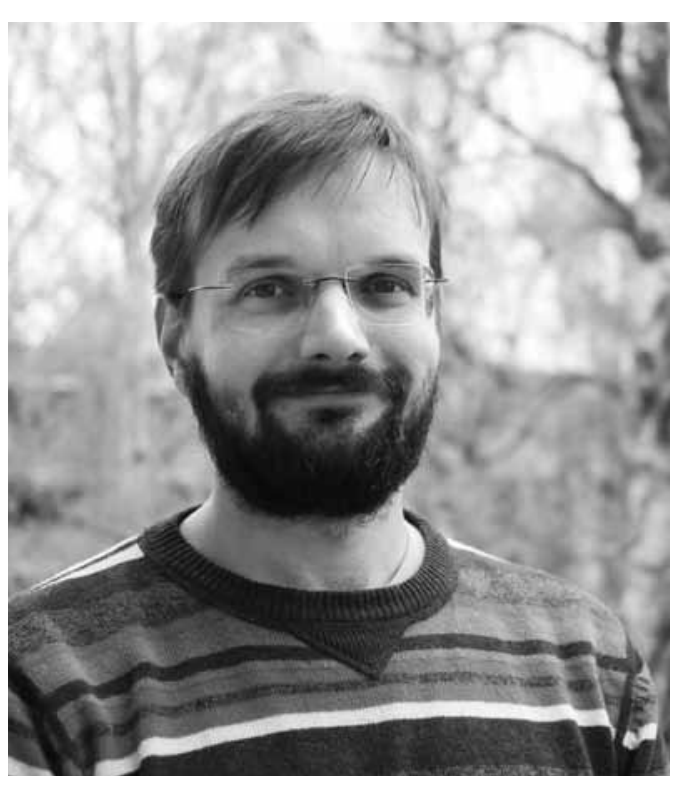

"Hain etäisyyttä väitöskirjaprosessiin ohjausalan maisteriopinnoista", ohjausalan tutkijaksi siirtyvä Toni

rakensivat työväenluokkaista maskuliinisuutta, jok osoittautui koulutuspolitiikassa toistettuja stereoty-
TEOREETTISESTI NOJAAN kriittiseen kasvatus- ja koulutussosiologiaan - Joensuun sosiologian laitos jätti minuun vahvan jälkensä. Minua kiinnostaa, miten yhteiskunnassa vallitsevat normatiiviset odotukset ja ihanneyksilön mallit rajaavat ja sulkevat osan ihmisistä ulkopuolelle.

Metodologisesti olen kiinnostunut siitä, miten hienovaraiset erot näkyvät tutkimusvuorovaikutuksessa. Ohjauksen alalla toimiessani taas pohdin, miten erot ovat läsnä ohjausvuorovaikutuksessa ja miten niitä voidaan nostaa esiin ja problematisoida ohjauksessa - leimaamatta ihmisiä.

JOS EN TUTKISI, työskentelisin ohjausalalla. Väitöstutkimuksen synkimmät hetket ohjasivat hakemaan henkistä tilaa ohjausalan maisteriopinnoista, jotka valmistuivat suunnilleen samaan aikaan väitöskirjan kanssa. Yhteiskuntatieteiden tohtorin tutkinto sosiologiasta ja kasvatustieteen maisterin tutkinto ohjauksesta ovat hyvä yhdistelmä.

Ohjauksen alan käytännön työ ja vuorovaikutustilanteet kiehtovat minua erityisesti siksi, että olen mieltänyt itseni pitkään sisäänpäin kääntyneeksi ihmiseksi ja kömpelöksi vuorovaikuttajaksi. Voin haastaa käsityksiä itsestäni.

AIKUISKASVATUSTIEDETTÄ TARVITAAN yhteiskunnassa tunnistamaan kasvatuksen paikkoja, kuten ratkomaan kysymyksiä siitä, kuinka tukea aikuisia kestävän tulevaisuuden rakentajina ja vaikuttajina.

Ohjaan kandidaattitöitä, ja keskusteluissa töiden aiheista opiskelijat ovat nostaneet esiin muun muassa aikuisten ympäristö-, media- ja kansalaiskasvatuksen, jotka kohdentuvat usein lapsiin ja nuoriin. Aikuisetkin tarvitsevat kuitenkin jatkuvaa tukea identiteettinsä uudelleen arviointiin.

PARAIKAA TUTKIN, miten korkeakouluopiskelijat vastaavat yhteiskunnallisiin paineisiin ja normatiivisiin odotuksiin, jotka koskevat opintojen edistämistä, opintoajan tarkoituksenmukaista käyttöä ja työmarkkinapotentiaalista huolehtimista. Olemme haastatelleet

Sarja vie aikuiskasvatuksen tutkijan arkeen ja verkostoihin. Sen tuottaa Aikuiskasvatuksen Tutkimusseura. generalistialojen kandidaattivaiheen opiskelijoita. Yhtena erityisteemana keskityn miesten tapoihin vastata opintoja ja uran rakentamista koskeviin odotuksiin. Opiskelijamiehet rakentavat nykyään maskuliinisuutta korostamalla pystyvyyttään verkostoitujina ja osaamispääomansa määrätietoisina kasvattajina.

Vuoden loppuun saakka työskentelen yliopistonlehtorina kasvatustieteen ja aikuiskasvatustieteen oppiaineissa Itä-Suomen yliopistossa. Ensi vuoden alussa aloitan tutkijatohtorina vakinaistamispolulla saman yliopiston ohjauksen koulutuksessa.

Odotan innostuneena sirtymää tutkijaksi. Minua kiinnostavat erityisesti aikuisohjaus ja uraohjaus sekä ylipäätään ohjaus itsessään, laaja-alaisena kenttänä. Usein se mielletään edelleen opinto-ohjaukseksi koulukontekstissa.

KUN EN TUTKI, pyöritän lapsiperheen arkea. Vapaaaikani menee käytännössä kokonaan perheen kanssa, lasten kanssa.

\section{Klassikko, johon palaan}

Miestutkijana ja luokkatutkijana valintani ovat kenties yllätyksettömiä, mutta pidän metodologisesti näiden kirjoittajien käsityöläisen otteesta tutkimukseen ja teoreettiseen ajatteluun

R. W. Connellin Masculinities (Polity Press 1995) on miestutkimuksen sekä ylistetty että arvosteltu klassikko. Kaikkien miestutkijoiden on muodostettava kanta Connellin teoretisointiin monenlaisista maskulinisuuksista, miehenä olemisen muodoista, jotka järjestyvät suhteessa hegemoniseen maskuliinisuuteen. Vahva ja omaleimainen teoria sukupuolijärjestyksestä.

Matti Kortteisen Kunnian kentät - Suomalainen palkkatyö kulttuurisena muotona (Hanki ja jää 1992) on oman aikansa työelämän kysymyksiin pureutuva tutkimus. Se nostaa esiin syviä kulttuurisia juonteita, joita voi yhä tunnistaa työläiskulttuurissa. Teos edustaa tutkimuksen tekemisen käsityötaitoa. Väitöskirjaa tehdessäni palasin toistuvasti inmettelemään, miten Kortteinen rakentaa tulkintojaan. 